\title{
Constraints and Scope of Betel Leaf Production in Bihar
}

\author{
Bipul Kumar, S.M. Rahaman", M.K. Wadhwani and Nitu Kumari
}

Department of Agricultural Economics, Bihar Agricultural University, Sabour, Bhagalpur, India

*Corresponding author: rehmanbau@gmail.com (ORCID ID: 0000-0002-8025-8508)

Received: $19-09-2021$

Revised: 28-11-2021

Accepted: 16-12-2021

\begin{abstract}
The study attempted to critically review the status and scope of betel vine, specifically to Deo block of Aurangabad district of Bihar. Betel vine cultivation faces a serious drawback and concern to the small holder farmers. The result revealed that the most important constraints for betel vine cultivation was boroj preparation, heavy incidence of pest and diseases, high price fluctuations of betel leaves and high wages of labour as well as high input costs. The farmers also identified that lack of storage facilities and high post harvest losses as the factors that limits the cultivation of betel vines. There was also lack of labour availability and proper market information to the farmers which hampers its production, however, excess summer heat and scorching of betel leaves remains as the major concern to the farmers. Despite being several constraints farmers continue the cultivation of betel vine as it generates regular and quick cash income and offers higher net returns as compared to other crops. Betel vine cultivation also offers better opportunity for engaging family labour which makes inspection of the field easy as joint management of the farm requires less inspection.

\section{HIGHLIGHTS}

( Betel vine cultivation remains as the tradition among many farmers which enables them to produce betel leaf inspite of several constraints.

- Wastage of betel leaves due to scorching heat, drying, discoloring etc. may be avoided by adopting new and improved techniques of cultivation and can be put to other alternative uses.
\end{abstract}

Keywords: Betel leave, Bihar, constraints, opportunity, prospects

Betel vine is an evergreen perennial and shade loving climber, botanically known as Piper betle L. belonging to piperaceae family. Major betel leaf growing countries in the world are India, Bangladesh, Thailand and Sri Lanka. In India, betel leaf is mostly grown in states of Assam, Andhra Pradesh, Bihar, Gujarat, Odisha, Karnataka, Madhya Pradesh, Rajasthan, West Bengal and Maharashtra. There are about 100 varieties of betel vine grown across the world, out of which about 40 cultivars are found in India and 30 in West Bengal (Guha, 1997; Maity, 1989; Samanta, 1994). In India betel vine is grown in over 50,000 ha area with estimated annual turnover of ₹ 1000 crores. India exported 10,386.52 MT of betel leaves around the world worth of ₹ 37.60 crores during 2019-20. India is the major exporter of betel leaves to countries like Afghanistan, Australia,
Bangladesh, Canada, France, Germany, Hongkong, Kenya, Nepal, United Kingdom, UAE, Saudi Arabia, Oman, Pakistan, Qatar, USA, Yemen and United Kingdom (Mandal and Mandal, 2016). Betel vine is cultivated as an important cash crop in India but still a little systematic research has been made so far on economics of production and marketing of betel vine despite having significant contribution to the income and employment for small holder farmers. Thus, this study is conducted to document the constraints faced by betel leaf growers and underlying reasons that farmers continuing its

How to cite this article: Kumar, B., Rahaman, S.M., Wadhwani, M.K. and Kumari, N. (2021). Constraints and Scope of Betel Leaf Production in Bihar. Economic Affairs, 66(04): 619-621.

Source of Support: None; Conflict of Interest: None (c) 
production. Due to its capital and labour intensive nature its cultivation offers perennial income and employment to the farmers and has shifted the paradigm in the farm economy in West Bengal (Chandra \& Sagar, 2004). Many farmers were shifting from betel vine cultivation to other crops because of price uncertainty in the local market and also due to lack of credit facilities, although its cultivation was profitable (Absar, 2015). Further, as far as generation of employment is concerned, approximately 20 million people derive their livelihoods directly or indirectly from handling, processing, production, transportation, and marketing of betel leaves in India (Guha, 2006). Betel leaf usage is intrinsically interwoven into the fabric of Indian and tradition and culture (Pavithra, 2016).

\section{MATERIALS AND METHODS}

Data \& Methodology: The author attempted a case study on betel vine cultivation in Aurangabad district of Bihar. Aurangabad district was purposively selected as the farmers of this region practices traditional method to cultivate betel vine and no proper marketing functionaries are being operated here. So, to ascertain the problems and find out the solution Aurangabad district has been selected purposively. Exploratory research design was employed for selection of villages. From Aurangabad district four villages were selected. From each village, 25 farmers were selected employing snowball sampling technique totaling a sample size of 100 farmers. Primary data was collected from 100 betel leaf grower through snowball sampling technique from Deo block of Aurangabad district of Bihar with the help of pretested schedule by personal interview method.

\section{Analytical Technique}

Garrett's Ranking Technique: The prioritizing of constraints and underlying reasons of continuance of betel vine cultivation was done using Garrett's Ranking Technique. In this method, respondents were asked to rank the specific constraints faced by them according to their own perception in descending order. The assigned rank was converted into respective percentage position which was subsequently transferred into Garrett score using Garrett's table. For each constraint, scores of individual respondents were added together and their mean was calculated using following formula:

Per cent Position $=100 *\left(R_{i j}-0.50\right) / N_{j}$

where,

$R_{i j}=$ Rank given for the $i^{\text {th }}$ item by the $j^{\text {th }}$ individual and

$N_{j}=$ Number of items ranked by the $j^{\text {th }}$ individual .

Thus, mean score for each constraint was arranged in descending order and ranked following the decision criterion that higher the value, the more important is the order of preferences by respondents (Rahaman et al. 2013).

\section{RESULTS AND DISCUSSION}

Table 1 represents the constraints faced by the betel vine growers in cultivation of betel vine of the sampled respondents. The result revealed that the most important constraint of the betel vine growers was preparation of boroj every year which ranked first with the mean score of 83.00 followed by heavy incidence of pests and diseases infestation with and high price fluctuation of betel leaves with mean score of 72.00 and 60.60 respectively. Other constraints associated with betel vine cultivation were high wages of labour, high costs of input, lack of storage facility, high post harvest losses, lack of labour availability, excess summer heat and leaf scorching and lack of proper market information etc.

Table 1: Constraints faced by the sampled betel vine farmers from Aurangabad district of Bihar

\begin{tabular}{|c|c|c|c|}
\hline $\begin{array}{l}\text { Sl. } \\
\text { No. }\end{array}$ & Constraints & $\begin{array}{l}\text { Garrett } \\
\text { score }\end{array}$ & Rank \\
\hline 1 & Boroj preparation in every year & 83.00 & I \\
\hline 2 & $\begin{array}{l}\text { Heavy incidence of Pests and } \\
\text { Disease infestation }\end{array}$ & 72.00 & II \\
\hline 3 & $\begin{array}{l}\text { High price Fluctuation of betel } \\
\text { leaves }\end{array}$ & 60.60 & III \\
\hline 4 & High wages of labour & 60.00 & IV \\
\hline 5 & High costs of input & 58.80 & $\mathrm{~V}$ \\
\hline 6 & Lack of storage facility & 43.42 & VI \\
\hline 7 & High Post Harvest losses & 42.38 & VII \\
\hline 8 & Lack of labour availability & 31.00 & VIII \\
\hline 9 & $\begin{array}{l}\text { Excess summer heat and leaf } \\
\text { scorching }\end{array}$ & 30.36 & IX \\
\hline 10 & Lack of proper market information & 17.33 & $x$ \\
\hline
\end{tabular}


Table 2 represents the underlying reasons for continuity of betel vine cultivation by the sampled respondents. It was observed that the capacity to generate regular and quick cash income ranked first with mean score of 81.00 followed by higher returns compared to other crops and better opportunity of engagement of family labour with mean score of 67.13 and 55.22 respectively. Other major reasons were joint management requires less inspection, convenient system for procuring planting material from neighbours and relatives, low production costs, traditional practices of betel vine cultivation among the farmers and existing good marketing network etc.

Table 2: Underlying reasons of continuity of betel vine cultivation by the sample farmers

\begin{tabular}{|c|c|c|c|}
\hline $\begin{array}{l}\text { Sl. } \\
\text { No. }\end{array}$ & Constraints & $\begin{array}{l}\text { Garrett } \\
\text { score }\end{array}$ & Rank \\
\hline 1 & $\begin{array}{l}\text { Generates regular and quick cash } \\
\text { income }\end{array}$ & 81.00 & $\mathrm{I}$ \\
\hline 2 & $\begin{array}{l}\text { Higher net returns compared to } \\
\text { other crops }\end{array}$ & 67.13 & II \\
\hline 3 & $\begin{array}{l}\text { Better opportunity of engagement } \\
\text { of family labour }\end{array}$ & 55.20 & III \\
\hline 4 & $\begin{array}{l}\text { Joint management requires less } \\
\text { inspection }\end{array}$ & 48.05 & IV \\
\hline 5 & $\begin{array}{l}\text { Convenient system for procuring } \\
\text { planting material from neighbours } \\
\text { and relatives }\end{array}$ & 42.00 & V \\
\hline 6 & $\begin{array}{l}\text { Low production management } \\
\text { costs }\end{array}$ & 37.00 & VI \\
\hline 7 & $\begin{array}{l}\text { Traditional practices of betel vine } \\
\text { cultivation among the farmers }\end{array}$ & 24.49 & VII \\
\hline 8 & Existing good marketing network & 22.51 & VIII \\
\hline
\end{tabular}

\section{CONCLUSION}

It can be concluded that the major constraints faced by the betel vine farmers were every year boroj preparation (Garrett score 83.00) followed by heavy incidence of pest and diseases and price fluctuation etc. Besides these problems, the farmers continuing betel vine farming due to the capacity of the crop to generate regular cash income and higher net returns than competing crops. A good quantity of betel leaves were wasted due to scorching heat, drying, discoloring etc. due to lack of technical knowhow on possibility of alternative uses of betel leaves. For example extraction of betel leaf oil may be an alternative opportunity to reduce wastage.
Thus, installation of betel leaf oil extractor and linking to market will also enhance the betel vine farmers' income to a great extent. The power of betel leaves marketing was concentrated on few traders. Some of the farmers also tried to maximize their income through assuming the position of market intermediary in betel leaves marketing but it was mostly controlled by distant wholesaler or Merchant middleman. The lack of timely price information, and developing an organized marketing system will ensure a better price for the farmers.

\section{REFERENCES}

Absar, Nurul. 2015. Dam milche na, mathai haat paan chasir (in Bengail), Anandabazaar Ptraika (Bengali Daily), 22 ${ }^{\text {nd }}$ June 2015. http://www.anandabazar.com/state/howrah-betelfarmers-not-gettingactual-price-getting-tensed-1.163711

Chandra, G. and Sagar, R.L. 2004. Harvesting green gold: Cultivation of betelvine in sundarban. Indian Farmers Digest., 37(3): 5-13.

Garrett Henry, E. and Woodworth, R.S. 1969. Statistics in psychology and education. Vakils, Feffer and Simons Private Limited, Bombay, pp. 329.

Guha, P. 1997. "Paan Theke Kutir Silpa Sambhabana" (in Bengali). "Exploring Betel Leaves for Cottage Industry", pp. 15-19, In: Krishi, Khadya-O- Gramin Bikash Mela-A Booklet published by the Agricultural and Food Engineering Department, IIT, Kharagpur, India.

Guha, P. 2006. Betel Leaf: The Neglected Green Gold of India. (2): 87-93.

Maity, S. 1989. Extension Bulletin: The Betel vine. All India Coordinated Research Project on Betel vine, Indian Institute of Horticultural Research, Hessarghatta, Bangalore, India.

Mandal, A. and Mandal, S. 2016. Financial feasibility and constraints of Betel vine cultivation in coastal areas of Sundarbans, West Bengal. J. Indian Soc. of Coastal Agric. Res., 34(1): 148-155.

Pavithra, H.K. 2016. An economic analysis of production and marketing of betel leaf- a study in Tumkur District, Karnataka. M.Sc., thesis. University of Agricultural Sciences, Bangalore - 560065 .

Rahaman, S.M., Bera, B.K. and Ananth, G.S. 2013. A study on problems and constraints in production and marketing of fish in West Bengal. J. Crop and Weed, 9(1): 110-113.

Samanta, C. 1994. Paan chaser samasyabali-o-samadhan: Ektisamikkha (In Bengali): "A Report on the Problems and Solutions of Betel Vine Cultivation". A booklet published by Mr. H. R. Adhikari, C-2/16, Karunamoyee, Salt Lake City, Kolkata-64 (WB), India.

http://apeda.gov.in/apedawebsite/SubHead_Products/ Betel_Leaves_Nuts.htm 
